\title{
Computer-Aided Acquisition of Writing Skills
}

\author{
Citation for published version (APA):
}

Verhoef, R., \& Tomic, W. (1996). Computer-Aided Acquisition of Writing Skills. Curriculum and Teaching, 11(1), 3-21. https://doi.org/10.7459/ct/11.1.02

DOI:

$10.7459 / \mathrm{ct} / 11.1 .02$

Document status and date:

Published: 01/01/1996

Document Version:

Publisher's PDF, also known as Version of record

Please check the document version of this publication:

- A submitted manuscript is the version of the article upon submission and before peer-review. There can be important differences between the submitted version and the official published version of record. People interested in the research are advised to contact the author for the final version of the publication, or visit the DOI to the publisher's website.

- The final author version and the galley proof are versions of the publication after peer review.

- The final published version features the final layout of the paper including the volume, issue and page numbers.

Link to publication

\section{General rights}

Copyright and moral rights for the publications made accessible in the public portal are retained by the authors and/or other copyright owners and it is a condition of accessing publications that users recognise and abide by the legal requirements associated with these rights.

- Users may download and print one copy of any publication from the public portal for the purpose of private study or research.

- You may not further distribute the material or use it for any profit-making activity or commercial gain

- You may freely distribute the URL identifying the publication in the public portal.

If the publication is distributed under the terms of Article 25fa of the Dutch Copyright Act, indicated by the "Taverne" license above, please follow below link for the End User Agreement:

https://www.ou.nl/taverne-agreement

Take down policy

If you believe that this document breaches copyright please contact us at:

pure-support@ou.nl

providing details and we will investigate your claim.

Downloaded from https://research.ou.nl/ on date: 26 Apr. 2023 


\title{
COMPUTER-AIDED ACQUISITION OF WRITING SKILLS
}

\author{
RIKA VERHOEF \\ and \\ WELKO TOMIC \\ The Open University, The Netherlands
}

\begin{abstract}
This article presents the results of a review of the literature questioning whether and to what extent computers can be used as a means of instruction for the guided acquisition of communicative writing skills in higher education. To answer this question, the present paper first explores the characteristics of acquiring these skills from a cognitive-psychological perspective, as well as the characteristics and behaviour of expert writers. On this basis, the paper then describes whether and how computeraided instruction can relieve teachers of certain duties associated with writing instruction, allowing them more time to perform tasks which fully utilise their unique capabilities.
\end{abstract}

\section{Computer-Aided Acquisition of Writing Skills}

School or professional writing assignments are not always greeted with cries of enthusiasm. Many people find it a protracted and exhausting activity to put conclusions, results or ideas down on paper in a coherent, logical fashion, while simultaneously keeping an eye on the arrangement of the material, sentence structure, word choice and spelling.

In higher education, term papers, theses or research reports are written forms of communication that play an important role in the curriculum. That is why in this article writing skills are defined as the ability to write argumentative and/or expository texts. Skill in writing can thus be described as the competent, functional, efficient use of written language as appropriate in a given context. By definition the writing process depends on the technology that allows writers to anchor their ideas in a more or less permanent way.

Research into writing skills has only been developed in the past twenty-five years (Van der Geest, 1992), the same period during which both writing technology and writing instruction underwent a dramatic transformation thanks to the introduction of computers.

Writing skills are a type of cognitive skill. The latter can be classified according to their level of complexity (Gagne and Briggs, 1979). Once a person has achieved a particular level of skill, he or she is ready to take on a higher organisational level or "bigger chunk" (Gleitman, 1991). The same is true of writing skills. The problems to be solved are highly complex, implying that activities must be performed at various different levels, all of which are related and influence one another reciprocally. For instance, a writer 
should never forget his/her readership; he/she should ensure that the argumentative structure is balanced; the writer should also make an appeal to long-term memory, set goals and phrase sentences clearly.

In this article we base our discussion on the basic premises of cognitive psychology, the most important view being that people are autonomous, intentional beings who interact with the external world, and that the mind is a general-purpose, symbol processing system (Eysenck and Keane, 1990). The article focuses on the mental processes such as they occur during the writing process. We also discuss the communicative context, which can affect mental processes, and the specific reading skills required whenever writing is preceded by a literature review. This means that we do not focus on writing as an art, but as a means of written communication involving activities such as informing, persuading, or instructing.

The article is organised in the following way. We first describe a general model of writing as a cognitive process. We then identify differences between experienced and inexperienced writers as found in the literature. Next we briefly discuss the level of writing skills as found among students in higher education, after which we explore how computers might contribute to writing instruction. After sketching various advancements in the computer world, we close with a discussion of several implementation criteria which may be important when introducing computer-aided instruction.

\section{Model of the Writing Process}

In this article, writing is considered a process. It is viewed as a specific form of problem-solving, within the general theory of problem-solving as described by Newell and Simon (1972). Hayes and Flower (1980) agree that almost every study on the subject of writing considers writing as a problem-solving activity consisting of a number of cognitive processes. Writing is a complex cognitive task which is susceptible to ambiguities of many different kinds, partly because of the many simultaneous cognitive demands made on the writer. In other words, writing means considering many things simultaneously, for example "is the message getting through to this particular target group"?; or "is this the right goal and the appropriate phrasing for the assumed readers"?

As our point of departure for the writing process, we will make use of the most familiar model within the cognitive approach, developed by Hayes and Flower (1980). With the exception of an alternative model proposed by de Beaugrande (1983), there are apparently no other competing models. In this model, the writing process resides in short-term memory or working memory. The subprocesses are planning, formulating, and revising. The writing process is influenced by the task environment and by long-term memory, and it results in a written text. An internal monitor determines when the writer switches between the various subprocesses. We first briefly discuss the individual components of this model, and then add two components which may be equally important for the finished written product: external sources (Kennedy, 1985) and the intention of the writer (Biggs, 1988), (see Figure 1 in the appendix).

\section{Task Environment}

The task environment furnishes the writer with information relevant to the completion of his or her task. This environment consists of the rhetorical problem and the text which has already been written. The rhetorical problem is the writing assignment itself, whether explicit or otherwise, which should provide a clear definition of the subject, the readers and the requirements which the text must meet. In addition, the problem serves to motivate the writer; for example, he/she may want to lodge a written complaint with a hospital concerning inappropriate medical treatment. It is likely that to a large extent the rhetorical 
problem determines the quality of the text. Clear-cut assignments and knowledge of the subject, text type required will likely help the writer to produce a satisfactory text. The second element of the task environment, the text which has already been written, is an important guideline for the writer. By checking what has already been put down on paper in the form of notes, diagrams and draft versions, the writer is better able to produce a cohesive text. In addition, the external storage of data means that the memory is under less strain.

Hayes and Flower (1980) assume that writers possess information on a variety of subjects, reader characteristics, and different text types, which they store in long-term memory. Throughout the writing process long-term memory interacts with the external sources, the task environment, and the subprocesses in short-term memory, where information is processed. Such processing changes the information stored in long-term memory; new information is acquired and, if possible, integrated into the existing cognitive structures.

According to Bereiter and Scardamalia (1985), it is often difficult to call up a sufficient amount of accurate information on a subject from long-term memory. They attribute this to the fragmented nature of the material covered in the classroom and the fact that the information acquired is not used actively. When learning new material, the students generally do not make a connection between new information and old on their own; the organisation of long-term memory leaves a great deal to be desired, making it harder to recall information.

\section{Planning}

The first subprocess in writing is planning. Planning is highly important in determining the quality of the finished written product. It is divided into: generating or collecting information, arranging information, and setting goals. The writer generates and organises relevant information into a meaningful whole in accordance with the goals that have been set (Janssen and Schilperoord, 1991). He or she might do this in the form of an outline or a diagram of the text content and structure.

\section{Formulation}

The second subprocess is formulation, i.e. translating ideas generated in the planning phase into written text. During this process the writer should be aware that he or she is writing in order to communicate and that the purpose of the text must be clear without the addition of gestures, intonation, expressions or another context (Flower, 1979). It is very important in the formulation process to take account of the purpose of the text. The writer can, for example, describe, express an opinion, present an argument, explain, persuade, or evaluate. The word choice, too, is important and must have the appropriate effect on the reader for whom the message is intended.

\section{Revision}

The third subprocess is revision. The entire writing process is iterative in nature and according to Kellogg (1987), revision is most effective in the initial phases. The purpose of revision is to increase text quality. This means that the text is compared with the original plan and with the writing assignment and goals, whether explicitly stated or not Revision also involves checking sentence structure, word choice, spelling, and punctuation (Van Gelderen, 1991).

\section{Monitor}

The monitor, which functions as a sort of internal supervisor, determines when the writer will carry out the various subprocesses and makes sure that long-term memory anc task environment interact. The order of the subprocesses is by no means linear; it is recur. 
sive in nature. Writers continuously switch from one subprocess to another. They take turns planning at word level, sentence level, and overall text level. Subprocesses interrupt one another. In particular, generating ideas and evaluating and rewriting the text the writer can draw on in every other phase.

Before writing an essay, a report or a term paper, writers are frequently obliged to carry out literature reviews. This requires close investigation of external sources like books, articles, and other forms of information. Kennedy (1985) studied the behaviour of students who based their writing assignment on source materials and found that the quality of their written products depended in part on the way in which they studied the sources. Students who read and studied the written sources more thoroughly, also engaged in more planning than their less able counterparts. Good writers read more actively: they underline text and write comments. They seem to interact with the author(s) whose texts they are reading. In the model developed by Hayes and Flower (1980), these external sources form part of the knowledge environment together with long-term memory, as concluded by Van der Loo (1992). The knowledge environment encompasses all the information that a writer uses when writing, including information stored in long-term memory and information taken from books, journals, or lectures, for example.

The activities carried out during the writing process and the quality of the written product are determined to a large extent by the writer's intention. Biggs (1988) concludes that two possible approaches to a writing task: the superficial approach and the in-depth approach, the latter producing a qualitatively better written product. In the superficial approach, writers see the assignment as a compulsory task in which they must demonstrate how much they know about a certain subject and for which they must get a passing grade. In the in-depth approach, writers view the assignment as a learning experience allowing them to integrate and deepen their knowledge of the subject. The two approaches lead to different working methods, which becomes particularly evident in the planning and revision phases.

\section{Differences Between Experienced and Inexperienced Writers}

Many researchers have observed that experienced and less experienced writers - also referred to as experts and novices, experienced and inexperienced writers or trained and untrained writers - differ in their approach. In the majority of investigations into differences between experienced and inexperienced writers the method of protocol analysis has been applied. The writer is asked to think aloud, verbally reprobing what he/she is doing while engaged in writing. In addition to protocol, the products of the writing process have also been analysed. The characteristics of experts and novices, and their sources are listed in Table 1 (See the appendix) and are organised according to the component of the model they relate to: task environment, knowledge environment, intention, planning, translating, revising, and monitor.

\section{Present Teaching Practice}

Less experienced, novice writers do not possess the component skills, presented in Table 1 , to the same extent, if they possess them at all, and must acquire these if they hope to improve their writing. According to Glover et al. (1990) there are no other factors related to poor writing, i.e. IQ, motivation, or academic achievement. Present teaching practice does not offer students sufficient guidance in acquiring writing skills. This has become obvious from a variety of sources: a study focusing on the results achieved in a rhetoric program in secondary education (Oostdam, 1991); an assessment study in secondary education (Kuhlemeier and Van den Bergh, 1989; Daems, Rymenans and Leroy, 1992); research into the language skills of first-year students in higher vocational educa- 
tion (Baltzer, Van Schooten and De Glopper, 1989); and the complaints of employers an (young) employees in business (Daems, Rymenans and Leroy, 1991). There are a numbe of reasons why this is so. First of all, until recently primary and secondary educatio appraised literacy mainly on the basis of technical aspects: being able to read at a certai speed without making mistakes and being able to write flawlessly using well-structure sentences (Verhoeven, 1992). Very little attention was given to matters of content.

Second, many teachers in secondary education are unable to transform the importanc that they themselves attach to formal writing into suitable instruction (Van der Gees 1992). Many school assignments, for example, consist of fill-in-the-blanks or completio exercises, so that students have little practice in producing a complete text requiring ther to organize the material logically (Rijlaarsdam, 1991). When students are told to write a essay, the teacher's feedback is generally in the form of red marks, an occasional stra comment and a grade. The students do get some practice, but very little instruction c usable feedback (Van der Geest, 1992).

Third, in higher education students spend more time acquiring knowledge than convey ing this knowledge to others, either within or outside the academic world, even thoug the transfer of knowledge is one of the explicit goals of higher education (Tomic, 1990).

Fourth, instructors in higher education too readily assume that new students hav already acquired the necessary writing skills or that they are capable of acquiring thes skills independently. A study conducted by the Dutch Center for Educational Research o the writing skills of first-year students in higher vocational education has disproved th assumption that students can easily master the necessary writing skills (Baitzer et al 1989). Most students performed below par with respect to both content and language ust The organisational aspect of writing was somewhat better. Consequently, Baltzer et a (1989) argue that students in higher education must be trained to write reports with wel] structured, sound arguments, so that they can avoid problems when writing their theses.

The most important factor influencing the level of writing skills of students in highe education is the amount of time spent writing during their previous school (Glover et al 1990). Since research has shown that primary and secondary education devotes so littl attention to communicative writing skills, we may assume that once students enter highe education, they run a greater risk of being functionally illiterate, that is, unable to commı nicate effectively in written form.

\section{Computer Use}

We may wonder whether educational practice can actually benefit from compute assistance in teaching writing skills. Two questions are relevant here: in the first plact can one teach the necessary component skills using computer-aided instruction? And sec ond, can we relieve instructors who teach writing skills that might theoretically be pel formed by computers, giving them more time to devote to activities that make full use $c$ their specific abilities?

To find answers to these questions, we discuss several advantages that the present ger eration of computers offers in acquiring the component skills described in the writin model of Hayes and Flower (1980). At the same time, we explore which tasks teache must continue to perform for the time being, specifically those which the computer is no capable of carrying out, at least not yet. We do not intend to present a complete survey c all the various options and computer programs, but hope rather to answer the two ques tions posed above within the present-day context.

To make use of the computer in writing instruction, students have to be able to wor 
with both the hardware and the software. The ability to use the computer supersedes all of the various component skills described in the model of the writing process, and it is a prerequisite for using this medium. Schools have caught on to the importance of teaching word processing. In the Netherlands most schools offer instruction in "WordPerfect", the word-processing program most commonly used there (Biemans and Van Meeuwen, 1992). The Dutch Interactive Teaching Office and the faculty of Educational Science at the University of Nijmegen have cooperated in designing an instructional computer program called WP-DAGOOG. The computer is used as a medium of instruction to teach individual students in secondary education basic word-processing skills in WordPerfect, relieving, teachers of a major portion of this labour-intensive task.

Some researchers have found that the use of word-processing programs has a positive influence on writing assignments. It is thought to improve text quality, facilitate revision and allow more insight into the writing process itself (Collins and Gentner, 1980; Van der Geest, 1986; Schwartz, Van der Geest and Smit-Kreuzen, 1992). Besides the positive impact on the writing assignment in general, various researchers have pointed out the specific advantages of word-processing programs when revising texts. Such programs make it easy to delete, replace or enter words, change the spelling and shift around sections of text. The writer consequently spends less time repeatedly rewriting the text, and can concentrate more on overall text quality (Collins and Gentner, 1980; 1990; Van der Geest, 1986; Schwartz et al., 1992). Not all of the research results on this subject confirm this positive effect, however.

Several programs have been developed to help writers with their writing assignment. Kozma (1991), for example, has developed a program to aid writers in planning and organising text. According to Kozma (1991), the program is not effective for improving text quality. Another example is the 'CONST' program, a portion of which (the list of questions) can be used to analyse writing assignments. CONST was developed at the University of Louvain in Belgium and provides computerised, intelligent writing assistance to students in higher education (Beeken, 1991). It consists of functionally structured databases and components which support and steer the text structuring process (list of questions in the form of instruction procedures and a diagrammatic description or visual representation of the text structure which has been developed or selected). The program can also be used in planning, formulating and revising a writing assignment. 'CONST' program has yet to be evaluated, so that the effectiveness of the program with respect to analysing writing assignments is unknown.

With the help of the above-mentioned program, computers can help to analyse the technical aspects of the assignment. The teacher continues to assess the chosen structure with a view to the assignment goals, the assignment subject and the readers. The abovementioned task, teacher assessment, comes into play when the actual contents of the text are being evaluated, for example when teacher and student discuss how the student went about analysing the assignment. The teacher can ask the student to clarify the line of reasoning which led him or her to choose a particular structure, focusing the student's attention on the processes underlying the product (the written outcome of the analysis).

The students' intention when beginning a writing assignment is largely determined by the motivation provided (Biggs, 1988). The degree of personal attention students receive, the amount of time the teacher spends on presenting and discussing the assignment and the teacher's body language are all clues which convey to the student how much importance the teacher attaches to the assignment. As a referent, the teacher consequently has a significant impact on the intention of the student.

The attractiveness of working with computers may contribute to positive feelings about 
writing assignments (Schwartz et al., 1992). Part of this attractiveness stems from the ease with which users can add diagrams and tables and revise the text (change the structure, cut and paste text, delete, alter text, check the spelling) and the neat appearance of the finished product. Dirkzwager and Mol (1987) have also noted positive changes in attitude when students use word-processing programs.

According to them, students are more motivated and work with greater concentration, and are more likely to revise texts. There is one distinct requirement, however: the available software must be suitable and user-friendly, and there must be enough hardware to go around (Van Zoelen and Boekenoogen, 1992). The changes in motivation mentioned above do not always lead to qualitative improvements in the written product, however.

Computers can function as a flexible information medium - a task for which they are highly suitable - when they are used to gather information via a database system and hypermedia (a combination of computers, video, CDs or laser discs where the computer runs the other media so that audio and visual information can be called up on demand in random order). The information can be tailored to an individual student's demands and is always available. If technically feasible, the system can be expanded further. By making use of this possibility, those teachers, who are used to offering tailored information to individual students can be relieved of this highly labour-intensive task.

Several authors have studied the impact of the computer on the planning process. Haas (1989) has investigated whether writing tools have any effect on the planning process. She asked expert and novice writers to produce texts using either pen and paper, a wordprocessing program, or both. The results revealed significant differences between the two media: writers who used a word-processing program spent less time on overall planning, made fewer plans before beginning to write, and did less planning at the level of the entire text than those who used pen and paper. These results applied to both expert and novice writers. This is an important finding, as it is precisely planning which is seen as a very crucial process. Haas (1989) has indicated that working with computers can also be a disadvantage: the computer screen shows less text at one time, so that the writer is unable to gain an overview of the entire text and consequently tends to concentrate on smaller units, both in the planning and the revision phase.

Van der Geest (1991) has described the Computer-Aided Writing Instruction Project (COSO) at the University of Twente. One of the objectives of the project was to develop and study the effectiveness of a writing composition curriculum emphasising planning at higher text levels, such as text content and paragraphs. This approach was supposed to counteract the negative effect of word-processing programs (see Haas, 1989). The computerised planning program did indeed prompt students to pay more attention to planning, with the result that the written products improved as well.

The computer's influence on the generating process is not always obvious. Computers used as 'surrogate teachers' during instruction have no discernible effect, according to Strickland (1987). He attributes this to instruction methods which have not been adapted to the specific opportunities which computers offer. His assumption is that the effect will become more significant when the computer is used as an intelligent hypermedium.

If the computer program makes use of a subject-specific database, then according to Gillis (1987) it can replace the teacher both in group or individual instruction. Constructing a database like this is a time-consuming task, but it only requires a one-time effort from teachers. Afterwards the exclusively with regard to a subject-specific database. Teachers can turn their attention to assessing text contents, taking into account which of the generated ideas have been selected (their relationships to one another and 
their relevance within the structure). Further evaluation will be required before we can assess the effectiveness of computer programs using subject-specific data-bases in any reliable fashion.

Less experienced writers can gain significant advantages in the formulation phase by using a word-processing program. It is precisely this group that runs the risk of focusing too much on spelling, punctuation and grammar, detracting from the attention that they should be giving to the higher levels (sections and text as a whole). An automatic monitor at the lower levels (choice of words, spelling, grammar) might help them shift their attention to higher levels.

At the word and sentence level, the computer can be utilized to steer text formulation, for example by means of the BOUWSTEEN and COGO programs, which assist in constructing and diagramming sentences (Pijls, Daelemans and Kempen, 1987) or a computer program developed by Van der Linden which teaches students to conjugate verbs (1990). For text writing, however, it is precisely the higher levels that are important: text cohesion and the proper organisation of the material into sections and paragraphs. These are levels which computers are unequipped to deal with as yet, leaving this as an important task for teachers.

A computer program which traces mistakes in texts by comparing patterns was designed by Hull, Ball, Fox, Levin and McCutchen (1987). The program concentrates on structure, punctuation, grammar, word choice and spelling, marking each occurrence of a particular type of mistake in the text so that the writer's attention is drawn to it. The program also explains the rule associated with the error and sometimes even shows how errors can be corrected. Hull et al. (1987) assume that many mistakes come about because writers do not apply the rules correctly. In addition, they also believe that this method not only teaches writers to correct their mistakes but also helps them to develop general analytic skills, including the ability to make rational choices.

As in the formulation phase, computers can be used to assess the lower levels of the revisions phase. The assessment of text as a whole continues to be the teacher's task. The student develops an internal monitor by internalising the evaluation criteria applied by the external monitor and explained during feedback. External monitors may be teachers, fellow-students or computer programs. A writer's internal monitor focuses on those levels which external monitors have brought to his or her attention. The internal monitor, then, develops separately from the medium, but it is nevertheless derived from the level on which the medium is focused during feedback. The theoretical nature of the discussion in this paragraph can be attributed to a lack of empirical data.

Suppose that a writer only obtained feedback from an external monitor in the form of a computer program, his or her internal monitor only would target the lower levels of writing. These are the levels about which the computer provides feedback, with the evaluation focusing mainly on the technical aspects of the writing process. To ensure that the internal monitor also learns to evaluate text at the higher levels, the writer must receive feedback from a teacher.

\section{New Developments in Computers}

Computer programs are shifting from computer-aided instruction in individual component skills, (i.e. programs focusing on spelling, sentence structure, planning, etc.) to integrated programs that fall within the realm of artificial intelligence: word-processing programs with planning modules, techniques for adding summaries, options which allow users to take separate notes and add these to the text, help screens that can be called up while working, graphics capabilities, access to database systems and checking options. It 
is even possible to link various programs, increasing the number of possibilities even further. Because such programs are still being developed, few evaluations have been carried out to date. In theory integrated programs should improve the writing process (Tennyson, 1989). One can wonder whether such advanced systems make the computer too intelligent, so that it is the computer that thinks instead of the user. The computer should offer people a learning environment in which they can use and develop their own intelligence.

Even advanced programs are of little use at the higher levels of writing, however. The underlying problem is that all of the input that the program is supposed to respond to and all of the possible feedback has to be called up into memory first. That means that a specific database has to be developed for each subject, an almost impossible task. Such programs are effective for restricted assignments which focus on a specific subject, and for which a data-base has already been designed, but run into problems when the writing assignment is open. Open assignments are hardly possible.

\section{Alternative Frameworks: Information-processing vs. Connectionism}

Because the present generation of computers is unable to cope with this enormous quantity of information, in recent years the neuronal network approach (connectionism) has attracted a great deal of attention. Until the 1990s, many cognitive scientists thought that the information-processing approach offered an appropriate explanation for human cognition. In the past decade, however, a competing framework has been established that is known as connectionism. We will describe this alternative framework only briefly within the scope of this article. The basic ideas of connectionism are that information can be decomposed into elements. Between these elements are a large number of connections. According to McClelland (1988) connectionism depicts human cognition as a network of connections between simple, but numerous, processing units.

There are differences between the information-processing approach and connectionism. First, the latter assumes that there are no particular rules that the system follows. Second, in contrast to the information-processing approach, where cognitive are assumed to occur in discrete phases (i.e. serially), the connectionist approach allows for parallel processing. Because many connections can be active at one and at the same time, the connectionist approach is more consistent with the functioning of the brain than the information-processing approach; the brain too is composed of many neurons that are connected to one another in various complex ways.

Until recently the computer metaphor was used to study human cognitive processing. Gradually the computer metaphor offered by the information-processing approach is being replaced by the brain metaphor (Rummelhart, 1989). For many researchers connectionism has become a more attractive alternative to explain human cognition, but also to design better computers which are better able to assist human cognitive processing. Instead of the computer, man has become the metaphor (Vroon and Draaisma, 1986). Although promising, the neuronal network approach can only be applied at the lower levels of writing skills. The approach works with programs which recognise patterns arising in a network that performs parallel processing. Unlike the usual computers which perform operations sequentially, neuronal networks are able to perform a whole range of operations simultaneously. This type of network does not function on the basis of predetermined if-then rules, nor are such networks instructed ahead of time what they are supposed to respond to and in which fashion: they themselves seek out solutions to problems and learn by experience (Boden, 1992).

As writing involves thinking and problem solving, it seems likely that parallel processing occurs during those activities (Eysenck and Keane, 1990). According to Boden 
(1992), the computer cannot replace the human brain, but it can help to generate ideas. A writer might, for example, indicate a starting situation. The computer offers relevant ideas, and the writer makes a selection, in this way steering the ideas. The advantages of this approach are that the computer is able to cover a much larger and more complex domain than human beings, and that it is not limited by preconceptions which might eliminate certain ideas ahead of time.

By using computer networks, students are able to send messages to other students by electronic mail. They write for a "live" public, and that can be highly motivating in and of itself. Students can also use electronic mail to provide one another with feedback on the material covered in their texts. Note that the feedback is not given by the computer, but by the person receiving the message. The computer is used only as a transmission medium.

\section{Implementation Criteria}

Until now the article has focused on the educational psychology side of computer use. When it comes to actual implementation in the teaching-learning process, however, we must be aware of other issues as well (Van Zoelen and Boekenoogen, 1992; Schwartz et al., 1992; Suppes, 1992).

Mirande and Leiblum (1990) have developed three sets of criteria for selecting applications for computer-aided instruction: economic criteria, educational criteria, and teacherspecific criteria.

Supper (1992) has identified a number of problems associated with computer-aided instruction. These are: how do we organize instruction in writing skills when using computers; how do we teach teachers and students to operate the equipment and run the programs; how can we make use of the student data acquired by the computer in a responsible fashion (for example test results)? He has also identified advantages, however. Instruction can be adapted to individual needs. Computer-aided instruction can be costeffective in the long run; it allows instruction to be decentralised and makes continuing adult education simpler.

\section{Concluding Remarks}

We stated that a person is considered to possess writing skills when he or she can express the message to be conveyed in written form, taking account of those for whom the message is intended and what the written text is supposed to achieve. The component skills needed to do this can be acquired in phases. Once acquired, these skills are integrated into a higher hierarchical structure (Gagne and Briggs, 1979) which is constructed simultaneously and which makes it possible to write a text that meets the requirements of the writing assignment, whether explicit or not.

Less experienced, novice writers do not possess these component skills to the same degree, if they possess them at all. They must first acquire these skills before they can improve their writing. A good internal monitor is the most obvious skill lacking, and current educational practice makes it the most difficult one to acquire.

Computer use seems to be attractive to students. Working with computers may contribute to positive feelings about writing assignments (Schwartz et al., 1992). Such feelings can be attributed to the ease with which students can manipulate their text. When students use word-processing programs, their attitude becomes more positive, they are more motivated and work with greater concentration (Dirkzwager and Mol. 1987).

One of the questions posed in the article is whether writing skills can be taught using computer-aided instruction. Most of the answers found in computer-aided writing 
research affirmative. Computer use has a positive impact on writing assignments in general. A computerised planning program, for example, seems to prompt students to pay more attention to planning. Not only are the students engaged in more planning, but the effect is that the written products improve as well (Vander Geest, 1991).

Word-processing programs offer specific advantages when students revise texts. They are more likely to take on the tasks of revising text in the first place. Most research on this subject confirms this positive effect (Collins and Gentner, 1980; Dirkzwager and Mol. 1987; 1990; Schwartz et al., 1992; Van der Geest, 1986).

The opportunities afforded by the computer for instruction in writing are well suited to the technical aspects of the writing process. There are computer programs available which focus on component skills at the lower levels, such as spelling and sentence structure. Such programs can often bring about an improvement in these skills, but it is unclear, yet, whether the knowledge acquired actually sticks and whether the writing process as a whole improves. Someone who has no trouble with spelling may still not be able to monitor his or her own writing process, and texts without spelling errors are not necessarily satisfactory texts (Schwartz et al., 1992). Suitable software is not always available (Van Zoelen and Boekenoogen, 1992); neither is there always enough hardware to go around. Students must be able to type reasonably well and work with hardware and software. Teachers often lack the knowledge and skills needed to run computers for educational purposes, and not every teacher is convinced of the usefulness of computer use in education, so that actual use is still limited (Ten Brummelhuis and Plomp, 1993). In addition, primary and secondary education tends to focus on the lower levels (spelling, verb conjugation, grammar, sentence structure), whereas higher education pays very little attention to these levels, focusing instead on text structure and content. Until now, teachers in higher education have had little to gain from computer programs which focus on writing skills at the lower level.

The contribution of computer-aided instruction to the acquisition of writing skills in higher education is rather limited. The computer can take over informing and 'mechanical' tasks (Robertson, 1986; Dirkzwager and Mol. 1987). This does not mean that less is required of teachers, but that their efforts must be redirected, giving alternative forms of teacher-student behaviour a chance. There is no need to focus primarily on technical aspects; instead attention can be given to discussing content. The teacher evaluates the contents of the text with a view to the student's underlying line of reasoning. Teachers can consider whether the student's message has been conveyed and why a particular message has prompted the student to take a particular approach. In this way, they examine the writing process and the communicative goals of writing, an aspect which has fallen by the wayside until now due to lack of time. The technical side of the finished product can be checked by computer to a large extent.

Development of such programs continues and researchers are involved in designing suitable programs. The focus is on integrated programs within the realm of artificial intelligence, with word-processing programs incorporating modules which, for example, assist the student in planning, adding summaries, checking options, and gaining access to database systems.

Researchers also agree that computer programs may relieve teachers giving them more time to devote to activities other than lower level writing. Computers can be used to teach individual students basic word-processing skills. There are programs to help students analyse the technical aspects of the writing assignment (Schwartz et al., 1992). Teachers who are used to offering tailored information to individual students, can be relieved of this task when computers are used to gather information via a database system. There are 
also programs which can trace mistakes in texts. The program marks each occurrence of a particular type of mistake in the text, i.e. sentence structure, punctuation, grammar, word choice, and spelling.

From an educational point of view, the findings and new developments mentioned above are significant and promising for the future of educational practice. The most imporlant factor influencing the level of writing skills of students in higher education is the amount of time spent writing during their previous school careers (Glover et al., $1990)$. Since research has shown that primary and secondary education devotes so little attention to communicative writing skills, we may conclude that once students enter higher education, they run a greater risk of being functionally illiterate, i.e. unable to communicate effectively in written form.

There should be a single, uninterrupted line of development in writing instruction extending from primary school right through to higher education. Writing skills are acquired in phases, by practising and receiving specific feedback on the results. By combining a teacher-oriented and an interactive approach (Rijlaarsdam, 1989), we can begin in primary school to provide instruction and practice in the effective components of writing, by clarifying those components that students are capable of handling at that time. This means being very sensitive to whether the necessary prior knowledge is present and the preceding levels of skill have been achieved. For the time being this seems like utopia.

\section{NOTE}

This study was supported in part by a grant from The Open University, The Netherlands.

\section{REFERENCES}

Applebee, A. N. (1984). Writing and reasoning. Review of Educational Research, 54, 577-596.

Baltzer, J. E., Schooten, E. van and Glopper, K. de, (1989). De taalvaardigheid van eerstejaars hbo-studenten. [Word skill of first-year students in higher vocational education]. Amsterdam: SCO.

Beeken, J. (1991). CONST: Computerondersteunde schrijftechnieken. [Computer-aided writing techniques]. Schrijven in moedertaal en vreemde taal, 2, 169-175.

Bereiter, C. (1980). Development in writing. In L. W. Gregg and Steinberg E. R. (Eds.), Cognitive processes in writing Hillsdale, New Jersey: Lawrence Erlbaum Associates.

Bereiter, C. and Scardamalia, M. (1985). Cognitive coping strategies and the problem of inert knowledge. In Chipman, S. F., Segal, J. W. and Glaser, R. (Eds.), Thinking and learning skills, vol. 2. Hillsdale, New Jersey: Lawrence Erlbaum Associates.

Biemans, H. and Meeuwen, D. van (1992). De computer ala pedagoog. [Computer as pedagogue]. Didaktief, 22, 2, 26-27.

Biggs, J. (1988). Approaches to learning and to essay writing. In Schmeck, R. R. (Ed.), Learning strategies and learning styles. New York: Plenum Press.

Boden, M. (1992). Creativiteit. Houten: Unieboek.

Brummelhuis, A. ten and Plomp, Tj. (1993). Computergebruik in het basisonderwijs. [Computer use in elementary education]. Znetermeer: Ministerie van Onderwijs en Wetenschappen.

Brummelhuis, A. ten and Plomp, Tj. (1993). Computergebruik in het voortgezet onderwijs. [Computer use in secondary education]. Zoetermeer: Ministerie van Onderwijs en Wetenschappen.

Bryson, M., Bereiter, C., Scardamalia M. and Joram, E. (1991). Going beyond the problem as given: problem solving in expert and novice writers. In Sternberg, R. J. and Frensch P.A. (Eds.), Complex problem solving: principles and mechanisms. Hillsdale, New Jersey: Lawrence Erlbaum Associates.

Collins, A. and Gentner, D. (1980). A framework for a cognitive theory of writing. In Gregg L. W. 
and Steinberg, E. R. (Eds.), Cognitive processes in writing. Hillsdale, New Jersey: Lawrence Erlbaum Associates.

Daems, F., Rymenans, R. and Leroy, G. (1991). Kwaliteit van het moedertaalonderwijs. [Quality of mother language education]. Antwerpen: Departement Didactiek en Kritiek.

Daems, F., Rymenans, R. and Leroy, G. (1992). Geletterdheid op achttien jaar. Peiling haar de lees-en schrijfvaardigheid bij het einde van het secundair onderwijs. [Literacy on the age of eighteen. Assessment of reading and writing skills at the end of secondary education]. Antwerpen: Departement Didactiek en Kritiek.

de Beaugrande, R. (1983). Linguistic and Cognitive Processes in Developmental Writing. International Review of Applied Linguistics in Language Teaching, 21, No. 2, 125-144.

Dirkzwager, A. and Mol. M. (1987). Onderwijskundig computergebruik. [Educational computer use]. Amsterdam: Addison-Wesley.

Eysenck, M. W., and Keane, M. T. (1990). Cognitive Psychology. Hove: Lawrence Erlbaum Associates.

Flower, L. (1979). Writer-based prose: a cognitive basis for problems in writing. College English, $41,1,19-37$.

Flower, L. and Hayes, J. (1980). The dynamics of composing: making plans and juggling constraints. In Gregg, L. W. and Steinberg, E. R. (Eds.), Cognitive processes in writing Hillsdale, New Jersey: Lawrence Erlbaum Associates.

Gagné, R. M. and Briggs, L. J. (1979). Principles of instructional design. New York: Holt, Rinchart and Winston.

Geest, Th. van der (1986). De computer in het schrijfonderwijs. Perspectief voor een procesbenadering. [Computer use in writing education. Perspective for a process approach]. Enschede: Universiteit Twente.

Geest, Th. van der (1991). Effecten van computerondersteund procesgericht schrijfonderwijs. [Effects of computer-aided writing instruction]. Schrijven in moedertaal en vreemde taal, 2, 157-168.

Geest, Th. van der (1992). Schrijfonderwijs: de moeizame stap van beschrijving naar voorschrift. [Writing education: the laborious step from description to prescription]. In Linden W. J. van der, Mommers, M. J. C., Peters, J. J. and Tomic, W. (Eds.), Onderwijskunde in de klas. Lisse: Swets and Zeitlinger.

Gein, J. van de (1991). Het benul van de zin. [The notion of the sentence]. Schrijven in moedertaal en vreemde taal, $40,2,102-111$.

Gelderen, A. van (1991). De kennis van 11-en 12-jarigen over tekstproduktie; leerlingen aan het woord. [Knowledge of 11 and 12 year old pupils about text production; pupils speaking]. Schrijven in moedertaal en vreemde taal, 40, 2, 68-79.

Gillis, P. D. (1987). Using computer technology to teach and evaluate prewriting. Computers and the Humanities, 21, 3-19.

Gleitman, H. (1991). Psychology, Third edition. New York: Norton.

Glover, J. A., Ronning, R. R. and Bruning, R. H. (1990). Cognitive psychology for teachers. New York: Macmillan Publishing Company.

Haas, Ch. (1989). How the writing medium shapes the writing process: effects of word processing on planning. Research in the teaching of English, 23, 2, 181-207.

Hayes, J. and Flower, L. (1980). Identifying the organization of writing processes. In Gregg, L. W. and Steinberg, E. R. (Eds.), Cognitive processes in writing. Hillsdale, New Jersey: Lawrence Erlbaum Associates.

Hull, G., Ball, C., Fox, J. L., Levin, L. and McCutchen, D. (1987). Computer detection of errors in natural language texts: some research on pattern-matching. Computers and the Humanities, 21. $103-118$.

Janssen, T. and Overmaat, M. (1990). Tekstopbouw en stelvaardigheid. Een onderzoek naar de effecten van twee experimentele methoden voor tekstopbouw. [Text structure and writing skills]. Lisse: Swets and Zeitlinger.

Janssen, D. and Schilperoord, J. (1991). Tekstplanning en tekstproduktie. [Text planning and text 
production]. Schrijven in moedertaal en vreemde taal, 40,2,80-91.

Kellogg, R. T. (1987). Writing performance, effects of cognitive strategies. Written Communication, 4, 3, 269-298.

Kennedy, M. L. (1985). The composing process of college students writing from sources. Written Communication, 2, 4, 434-456.

Kozma, R. B. (1991). Computer-Based Writing Tools and the Cognitive Needs of Novice Writers. Computers and Composition: a Journal for Teachers of Writing, 8, No. 12, 31-45.

Kuhlemeier, H. and Bergh, H. van den (1989). De proefpeiling Nederlands: een onderzoek naar de haalbaarheid van peilingsonderzoek in het voortgezet onderwijs. [Feasibility evaluation study in secondary education]. Arnhem: CITO.

Linden, J. van der (1990). Effecten van computergestuurd spellingonderwijs. [Effects of computeraided spelling instruction]. Didaktief, 20, 6, 4-6.

Loo, M. van der (1992). Het individuele schrijfproces. [Individual writing process]. In Janssen, D. M. L., Hoven, P. J. van den, Münstermann, H. G. W., Stijnen, P. J. J. (Eds.), Beleidsnota's. Leiden: Stenfer Kroese.

McClelland, J. L. (1980). Connectionist Models and Psychological Evidence. Journal of Memory and Language, 27, 107-123.

Mirande, M. J. A. and Leiblum, M. L. (1992). De top-25 van een studierichting - over selectie en toepassingsmogelijkheden voor computerondersteund onderwijs-. [Top 25 of a departmentabout selection and application of computer-aided instruction]. Onderzoek van onderwijs, 5, 1921.

Newell, A., and Simon, H. A. (1972). Human problem solving. Englewood Cliffs, NJ: PrenticeHall.

Oostdam, R. J. (1991). Argumentatie in de peiling; Een aanbod-en prestatieneiling van argumentatievaardigheden in het voortgezet onderwijs. [Assessment of argumentation skills in secondary education]. Amsterdam: SCO.

Overmaat, M. (1991). Lezen en schrijven met behulp van tekstschema's. De effecten van experimenteel tekstschema-onderwijs in de bovenbouw van het voortgezet onderwijs. [Reading and writing with aid of text diagrams in upper grades of secondary education]. Lisse: Swets and Zeitlinger.

Pijls, F., Daelemans, W. and Kempen, G. (1987). Artificial intelligence tools for grammar and spelling instruction. Instructional Science, 16, 319-336.

Robertson, M. (1986). "Is anybody listening?": Responding to student writing. College Composition and Communication, 37, 1, 87-91.

Rijlaarsdam, G. (1989). De consequenties van schrijfonderzoek voor schrijfonderwijs. [Consequences of writing skill research for writing education]. Levende Talen, 440, $268-270$.

Rijlaarsiam, G. (1991). Intra- en intertalige transfer van schrijfvaardigheidsonderwijs. [Intra-and inter-language transfer of writing skills education]. Schrijven in moedertaal en vreemde taal, 40 , 2, 9-22.

Rumelhart, D. E. (1989). The architecture of mind: A connectionist approach. In M. I. Posner (Ed.), Foundations of Cognitive Science. (pp. 133-159). Cambridge: Bradford Books.

Sanders, T. (1991). Tekststructuur in teksten van onervaren schrijvers; van tekstanalyse naar een criterium voor tekstkwaliteit. [Text structure in texts of inexperienced writers; from text analysis to a criterion for text quality]. Schrijven in moedertaal en vreemde taal, 40, p. 35-46.

Schuurs, U. and Bergh, H. van den (1991). Geleide revisie: de effecten van twee soorten feedback. [Guided revision; effects of two types of feedback]. Schrijven in moedertaal en vreemde taal, $40,2,92-101$.

Schwanz, H. J., Geest, Th. van der and Smit-Kreuzen, M. (1992). Computers in writing instruction. International Journal of Educational Research, 17, 1, 37-49.

Steinberg, E.R. (1980). A garden of opportunities and a ticket of dangers. In Gregg, L. W. and Steinberg E. R. (Eds.), Cognitive processes in writing Hilisdale, New Jersey: Lawrence Erlbaum Associates.

Stotsky, S. (1990). on planning and writing plans-or beware of borrowed theories. College 
Composition and Communication, 41, 1, 37-57.

Strickland, J. (1987). Computers, invention, and the power to change student writing. Computers and Composition, 4, 7-26.

Suppes, P. (1992). International computers: past, present, and future. International Journal of Educational Research, 17. 1, 5-17.

Tennyson, R. D. (1989). Computer-based enhancements for the improvement of learning. In Dijkstra S., Hout-Wolters, B. H. A. M. van and Sijde, P. C. van der, (Eds.), Research on insrruction, design and effects. New Jersey: Englewood Cliffs.

Tomic, W. (1990). Het Nederlands onderwijs in hoofdlijnen. [Dutch education in main lines]. Heerlen: Open Universiteit.

Verhoeven, L. (1992). Handboek lees-en schrijfdidactiek. Functionele geletterheid in basis-en voortgezet onderwijs. [Text book of reading and writing education. Functional literacy in elementary and secondary education]. Lisse: Swets and Zeitlinger.

Vroon, P. A. and Draaisma, D. (1986). De mens als metafoor. [Man as metaphor]. Baarn: Ambo.

Zoelen, L. van and Boekenoogen, M. (1992). Computers in het basisonderwijs. [Computers in elementary education]. Didaktief, 22, 3, 21-23.

ADDRESS FOR CORRESPONDENCE: Dr Welko Tomic, The Open University, PO Box 2960, 6401 DJ Heerlen, The Netherlands. 
Appendix: Table 1

Major Differences Between Experienced and Inexperienced Writers

\begin{tabular}{|c|c|c|c|c|}
\hline $\begin{array}{l}\text { Components } \\
\text { of the Writing } \\
\text { Model }\end{array}$ & Activitics & $\begin{array}{l}\text { Exper- } \\
\text { ienced } \\
\text { Writers }\end{array}$ & $\begin{array}{l}\text { Inexper- } \\
\text { ienced } \\
\text { Writers }\end{array}$ & Source \\
\hline $\begin{array}{l}\text { Task- } \\
\text { environment }\end{array}$ & $\begin{array}{l}\text { Puts a great deal of } \\
\text { time into analysing the } \\
\text { assignment and clarifying } \\
\text { the assignment goals. } \\
\text { Starts writing directly } \\
\text { after the assignment is } \\
\text { given. }\end{array}$ & + & + & $\begin{array}{l}\text { Bryson et al. } \\
\text { Glover et al. } \\
\text { Rijlaarsdam, }\end{array}$ \\
\hline \multirow[t]{10}{*}{$\begin{array}{l}\text { Knowledge } \\
\text { Environment }\end{array}$} & $\begin{array}{l}\text { Either already knows a } \\
\text { great deal about the } \\
\text { subject or knows how } \\
\text { to acquire this } \\
\text { knowledge efficiently. }\end{array}$ & + & & $\begin{array}{l}\text { Rijlaarsdam, } \\
\text { Glover et al. }\end{array}$ \\
\hline & $\begin{array}{l}\text { Knowledge of the type } \\
\text { of text required. }\end{array}$ & + & & Van der Loo, \\
\hline & $\begin{array}{l}\text { Has developed solution } \\
\text { blueprints for the various } \\
\text { types of assignment and } \\
\text { makes use of these acquired } \\
\text { procedures to tackle a new } \\
\text { assignment. }\end{array}$ & + & & Bryson et al. \\
\hline & $\begin{array}{l}\text { Is able to size up } \\
\text { readership accurately and } \\
\text { select the information } \\
\text { that readers will need. }\end{array}$ & + & & $\begin{array}{l}\text { Bereiter, } 198 \\
\text { Flower, } 1979 \\
\text { Rijlaarsdam, }\end{array}$ \\
\hline & $\begin{array}{l}\text { Simply writes down everything } \\
\text { he/she knows about the } \\
\text { subject. }\end{array}$ & & + & Rijlaarsdam, \\
\hline & $\begin{array}{l}\text { Searches memory for } \\
\text { associated ideas targeling } \\
\text { similar goals, in this way } \\
\text { creating a hierarchical } \\
\text { order. }\end{array}$ & + & & $\begin{array}{l}\text { Biggs, } 1988 \\
\text { Bryson et al. } \\
\text { Rijlaarsdam, } \\
\text { Van Gelderen, }\end{array}$ \\
\hline & $\begin{array}{l}\text { Only in a later phase does } \\
\text { he/she try to recall } \\
\text { details relating to the } \\
\text { subject itself. }\end{array}$ & + & & \\
\hline & $\begin{array}{l}\text { Reads and rereads source } \\
\text { material actively. }\end{array}$ & + & & Rennedy, 1985 \\
\hline & $\begin{array}{l}\text { Scribbles comments in the } \\
\text { margins, underlines } \\
\text { passages in the text and } \\
\text { takes notes related to the } \\
\text { main idea of the text } \\
\text { while reading. }\end{array}$ & + & & $\begin{array}{l}\text { Rennedy, } 1985 \\
\text { Glover et al. }\end{array}$ \\
\hline & $\begin{array}{l}\text { Makes frequent use of } \\
\text { literal quotations. }\end{array}$ & & + & $\begin{array}{l}\text { Kennedy, } 1985 \\
\text { Rijlaarsdam, }\end{array}$ \\
\hline & 18 & & & \\
\hline
\end{tabular}


Uses his/her own words to

turn the information given

in the sources into a

cohesive whole.

\begin{tabular}{lll}
\hline Intention & + & Steinberg, 19 \\
In-depth approach. & Biggs, 1988 \\
Is intrinsically & Flower, 1979 \\
motivated to write. & Steinberg, 19 \\
Sees a writing assignment & Biggs, 1988 \\
as an opportunity to & Flower, 1979 \\
integrate and deepen hisi & \\
her own knowledge. & \\
Superficial approach. & \\
Writing is a compulsory & \\
assignment that he/she has & \\
to pass.
\end{tabular}

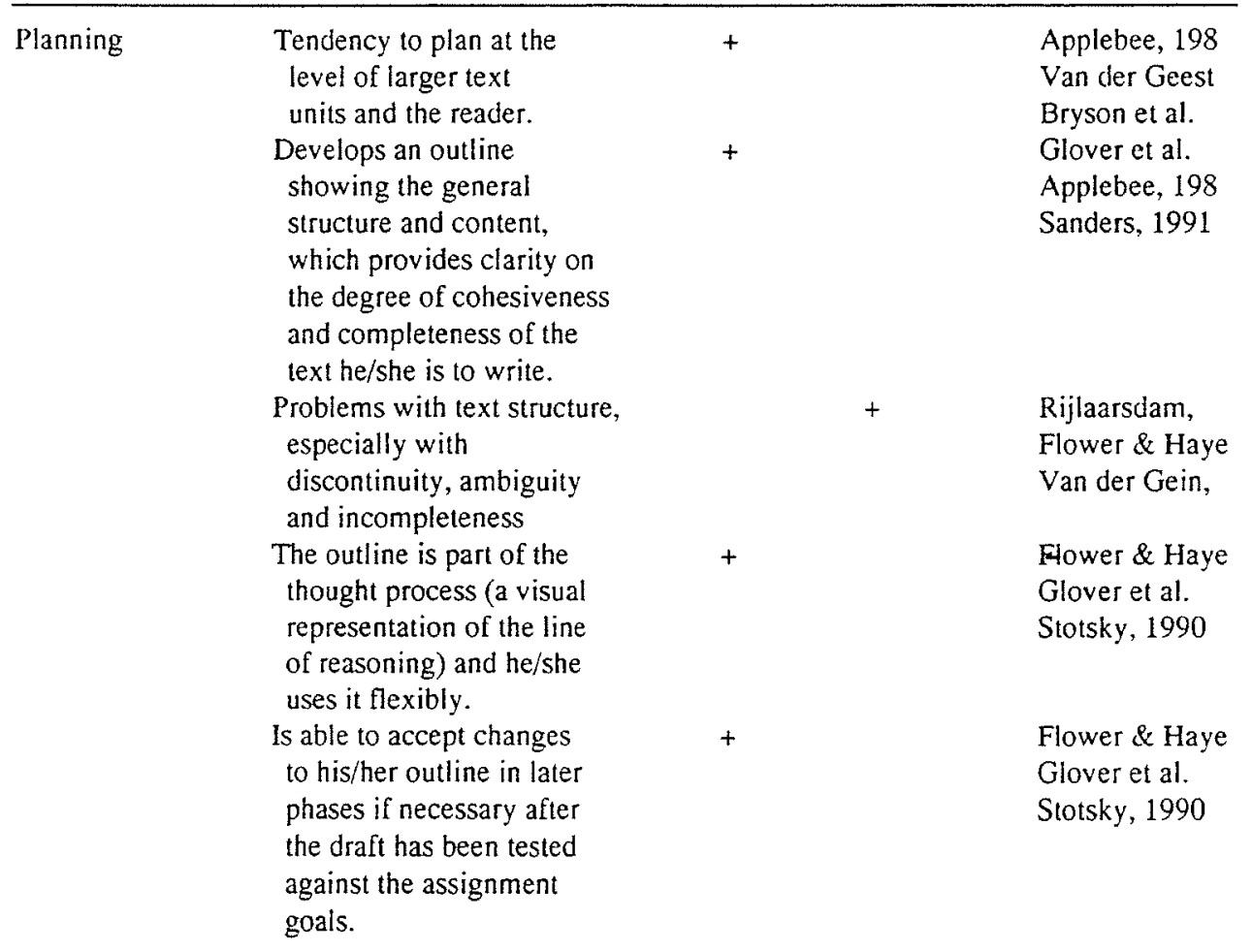

Translating

Falls back on speaking, or $+$

Van der Gein, more precisely, conversational skills and the interactive structure underlying these skills.

The formulation of ideas into

Rijlaarsdam, written text is partly Bryson et al. automatic.

Concentrates much effort on the core of the 
argument.

Is constantly preoccupied with checking spelling and grammar, and has difficuliy rocusing on the content.

Occasionally rereads large sections of text, making

Bryson et al. text cohesion more likely.

Frequently rereads small sections of text.

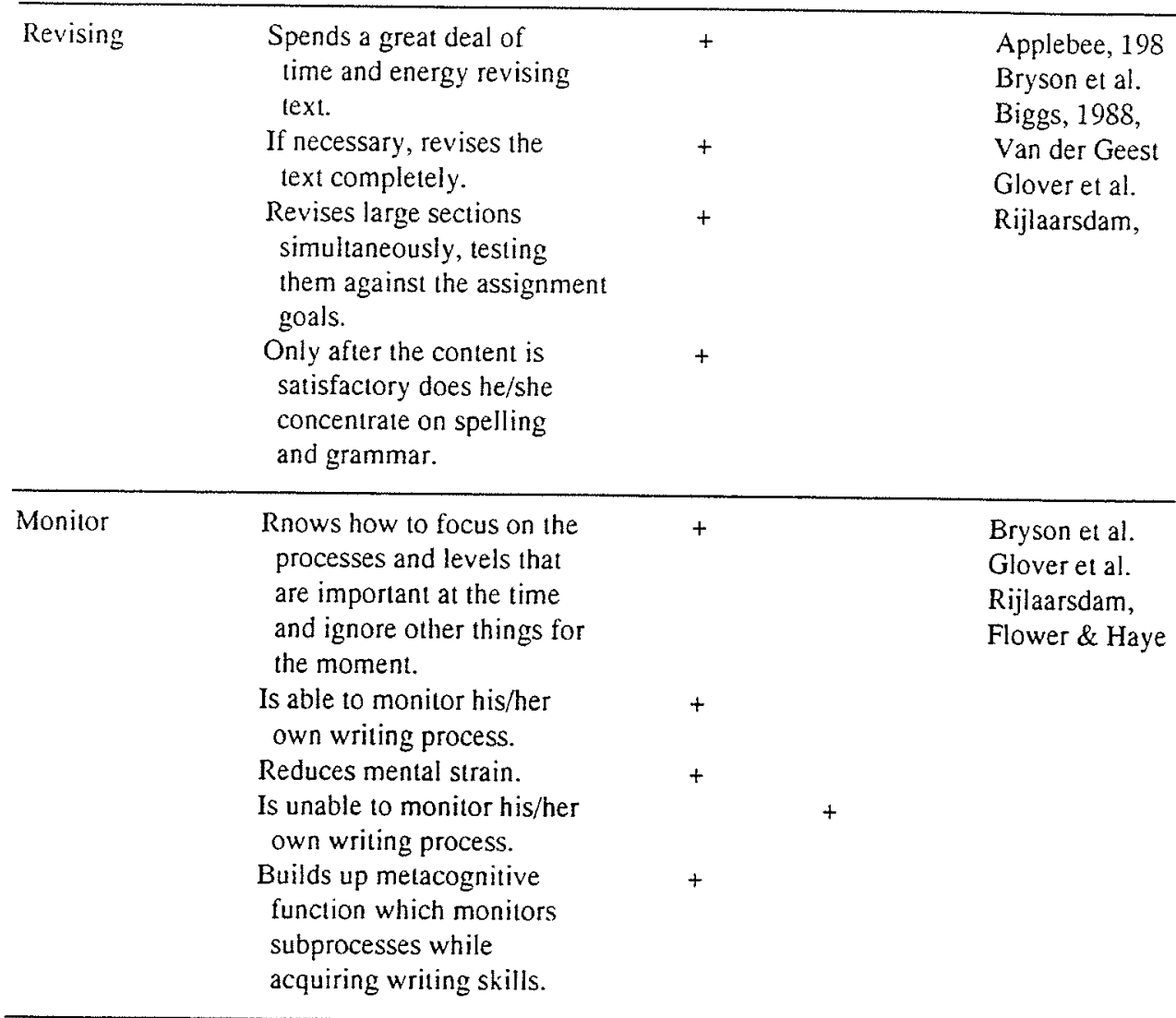

$+:$ means present 
Figure 1: A Model of the Writing Process Adapted from Hayes and Flower, 1980.

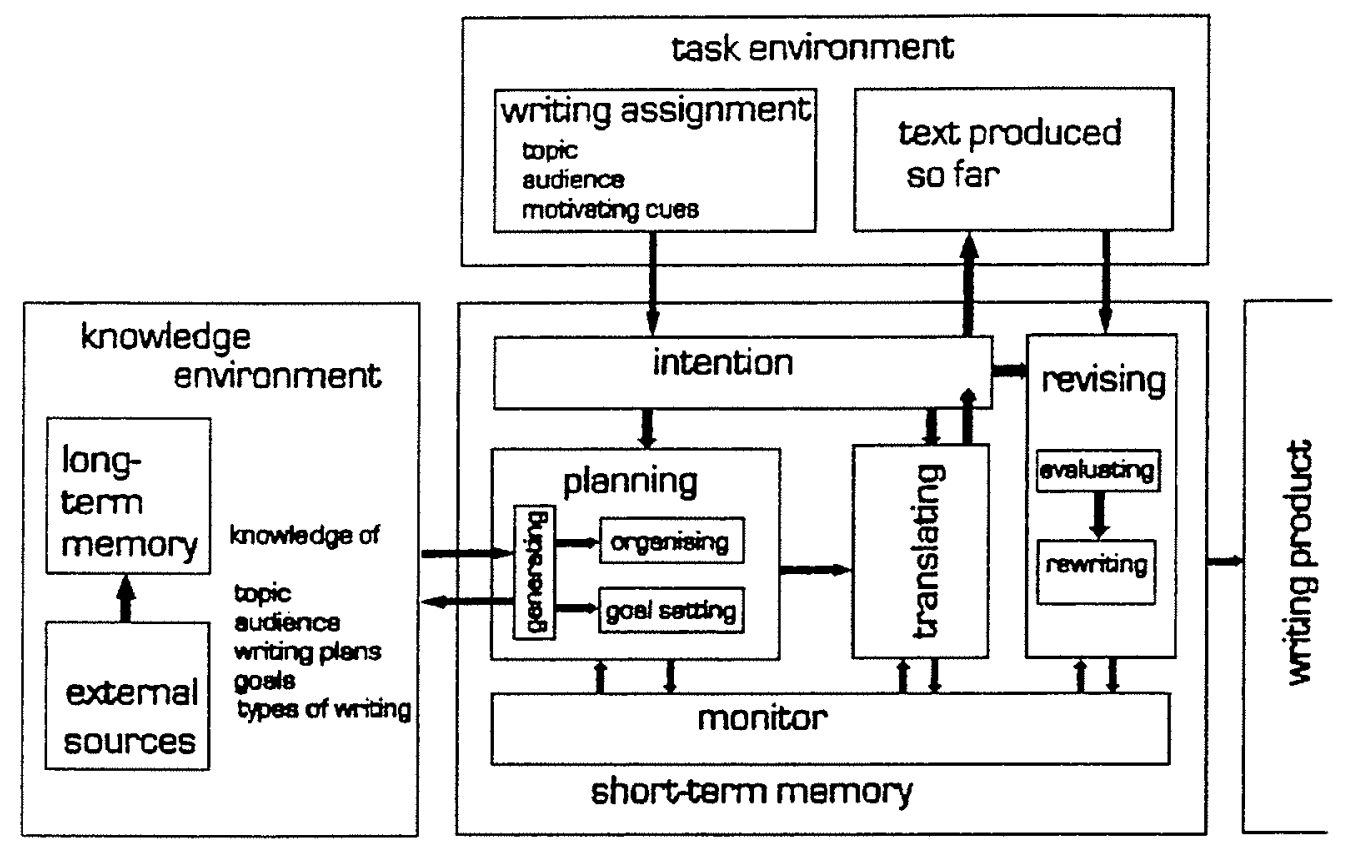

